\title{
POTENTIAL NA-ALGINATE EXTRACT FROM BROWN ALGAE sargassum sp. OF THE MANGO MATURATION PROCESS
}

\author{
Tanti Iryanti ${ }^{1 *}$, Abdul Wahid Wahab ${ }^{1 *}$, dan Rohani Bahar ${ }^{1}$ \\ ${ }^{1}$ Department of Chemistry, Faculty of Mathematics and Natural Sciences, Hasanuddin University, \\ Perintis Kemerdekaan Street KM 10, Tamalanrea Makasssar, Indonesia 90245 \\ *Corresponding author: nn5794aa.nhya94@gmail.com
}

\begin{abstract}
Abstrak. Ekstraksi Na-alginat dari Sargassum sp. dan penerapannya dalam pematangan mangga telah dilakukan. Penelitian ini bertujuan untuk mengetahui periode penyimpanan mangga dengan menggunakan larutan natrium alginat sebagai lapisan yang dapat dimakan dan konsentrasi optimum yang memiliki daya hambat maksimum untuk pematangan mangga. Hasil FTIR menunjukkan bahwa natrium alginat hasil ekstraksi memiliki gugus fungsi yang sama dengan natrium alginat di pabrik. Analisis kuantitatif menunjukkan bahwa kandungan natrium alginat hasil ekstraksi adalah 22,42\%, larutan natrium alginat $1 \%$ memiliki $\mathrm{pH} 10,97$ dan viskositas 90 cps, ukuran air natrium alginat adalah $11,27 \%$ dengan ukuran abu adalah $41,47 \%$. Dengan menguji kemampuan natrium alginat dilakukan pada mangga dengan metode perendaman dalam konsentrasi larutan dari 0-50 ppm. Pada konsentrasi $20 \mathrm{ppm}$ larutan menunjukkan bahwa periode penyimpanan maksimum sekitar 15 hari pada suhu kamar sementara tanpa perendaman hanya sekitar 5 hari. Dengan penelitian ini, kami menunjukkan bahwa natrium alginat berpotensi sebagai pelestarian buah.
\end{abstract}

Kata kunci: alginat, daya hambat, ekstraksi, periode penyimpanan.

\begin{abstract}
Extraction of Na-alginate from Sargassum sp. and its application in ripening mangoes has conducted. This research aimed to determine the mango storage period by using sodium alginate solution as edible coating and optimum concentration that has maximum inhibition power to the maturation the mango. The FTIR result shows that sodium alginate by the result of the extraction has the same similar functional group to the sodium alginate in the factory. Quantitative analysis show that content of sodium alginate as the result of the extraction is $22,42 \%$, sodium alginate solution is $1 \%$ has $\mathrm{pH} 10,97$ and the viscosity is $90 \mathrm{cps}$, the water measure of sodium alginate is $11,27 \%$ with the measure of ash is $41,47 \%$. By testing the ability of sodium alginate conducted on mango with submersion method in the solution concentration from $0-50 \mathrm{ppm}$. At a concentration of $20 \mathrm{ppm}$ solution shows that the maximum of storage period is about 15 days at room temperature while without submersion is just about 5 days. By this study, we indicate that sodium alginate potentially as coating fruit preservation.
\end{abstract}

Keywords: alginate, inhibition, extraction, storage period. 


\section{INTRODUCTION}

Seaweed is one of Indonesia's marine biological resources which has sufficient potential for both domestic and export needs. Today seaweed is becoming known by the wider community, especially the types of seaweed that have high economic value. Of the hundreds of types of seaweed in Indonesia, there are 5 types of high economic value such as Gracilaria, Gelidium, both agar producers, Eucheuma, Hypea, as producers of carrageenan, and Sargassum, as alginate producers (Siswati et al., 2002). At present the seaweed has not been fully utilized in Indonesia.

Sargassum sp. is one type of economically valuable seaweed, widely distributed in Indonesian waters, growing in large, protected and undulating waters in rock habitats (Kadi and Atmadja, 1988). Sargassum $s p$. very potential to be developed and used as a source of alginate which is much needed in the food and non-food industries (Indriani and Sumarsih, 2003).

In the food industry, alginate can be used as an ingredient to make edible packaging or better known as edible film or edible coating. The function of edible coating besides being able to protect food products, also the original appearance of the product can be maintained. In addition, edible packaging can be directly eaten and safe for the environment (Rehm, 2009).

Post-harvest technology in the world of agriculture greatly determines the quality of agricultural products. Handling of agricultural products, especially in maintaining freshness, wholeness, and health of the fruit will determine its economic value. After harvesting, the fruit will experience chemical changes, especially changes due to air respiration, changes in water content, arrangement of carbohydrate molecules, acid changes and changes in $\mathrm{pH}$ which eventually will cause the fruit to be damaged and eventually rot (Muchtadi and Tien, 1989) .

Mango is a type of fruit plant that is widely cultivated in South Sulawesi (BPTP, 2007). As with other fruits, after harvesting the mangoes will experience rapid damage such as discoloration due to enzymes and microbiological activity, which causes the mangoes to rot quickly and become damaged so they can no longer be consumed. Therefore an alternative is needed to preserve and extend the shelf life of the fruit, in order to improve its quality and economic value. Based on this, this study was conducted.

The purpose of this study was to test Na-alginate extract from brown algae, determine the optimum concentration of $\mathrm{Na}$-alginate for the ripening process of mangoes, and determine the average storage period of mangoes using Na-alginate extract.

\section{MATERIAL AND METHODS Materials}

The materials used in this study were Sargassum sp., golek's mangoes, Merck hydrochloric acid ( $\mathrm{HCl}$ p.a), sodium hydroxide ( $\mathrm{NaOH}$ p.a Merck), technical $\mathrm{NaOH}$, sodium carbonate (Merck $\mathrm{Na}_{2} \mathrm{CO}_{3}$ p.a), calcium chloride $\left(\mathrm{CaCl}_{2}\right.$ technical $)$, technical sodium hypochlorite $(\mathrm{NaOCl}), 95 \%$ isopropanol, 
Iodine, starch indicator, pp indicator, filter paper, aluminum foil, aquades.

\section{Procedures}

\section{Sample Prepration}

The extraction method was carried out on brown algae samples (Sargassum sp.) Collected from the study site by washing them thoroughly with fresh water, then drying them in direct sunlight. The sample is smoothed using a blender, then weighed as much as 10 grams.

\section{Sodium Alginate Extraction}

Sargassum powder as much as 10 grams was soaked in $100 \mathrm{~mL} \mathrm{5 \%} \mathrm{HCl}$ for 30 minutes then washed with distilled water, then extracted with $200 \mathrm{~mL}$ $\mathrm{Na} 2 \mathrm{CO} 32 \%$ with temperature $70{ }^{\circ} \mathrm{C}$ for 2 hours while stirring until it became paste, then diluted with $300 \mathrm{~mL}$ aquades and filtered with vacuum filter. After that, it was blanched by adding $50 \mathrm{~mL}$ of $5 \%$ $\mathrm{NaOCl}$ and adding $200 \mathrm{~mL}$ of $5 \% \mathrm{CaCl} 2$ and stirring until a white calcium alginate precipitate was formed, then filtered and rinsed. The gel formed is added $200 \mathrm{~mL}$ of $5 \% \mathrm{HCl}$ solution, then stirred to form alginic acid which is characterized by the emergence of clots in the upper part of the liquid, then filtered and rinsed. After that, alginic acid was added $200 \mathrm{~mL}$ of $10 \%$ $\mathrm{NaOH}$ solution, then stirred until Naalginate fibers were formed and then filtered and rinsed. For the purification process, added with $200 \mathrm{~mL}$ 95\% isopropanol then stirred and filtered. The precipitate is dried in an oven at $60{ }^{\circ} \mathrm{C}$. After drying, then mashed and weighed to determine the level of Na-alginate produced.

\section{Qualitative Analysis}

To determine the isomer of the functional groups of sodium alginate extracted from Sargassum sp. and sodium alginate from the plant is used with the FTIR spectrophotometer instrument.

\section{Quantitative Analysis \\ 4.1 Determination of Na-alginate levels}

$\% \mathrm{Na}-$ alginate $=\frac{\mathrm{Na}-\text { alginate }(\mathrm{g})}{\text { Sample }(\mathrm{g})} \times 100 \% \ldots 1$

\subsection{Determination of water content}

Dry empty porcelain cup is weighted and then weighed 1 gram sample then dried in oven at $100-105{ }^{\circ} \mathrm{C}$ for 3 hours, then cool in desiccator for 15 minutes then weighed, re-dried in oven for 30 minutes, cooled and weighed, carried out continuously until the difference between the two weighs is obtained not more than $0.01 \mathrm{~g}$. Weight loss shows the moisture content while the remaining weight is the solid material from the material.

$\%$ water $=\frac{\text { Initial weight }- \text { Weight }(\mathrm{g})}{\text { Initial Weight }(\mathrm{g})} \times 100 \% \ldots 2$

\subsection{Determination of Ash Content}

The Na-alginate sample is weighed 1 gram in the crucible which has been weighted, then heated to the substance. The rest of the sample in the crucible is moistened with $1 \mathrm{~mL}$ of nitric acid, then heated slowly until white does not occur again. Furthermore, it is put in the kiln and spawned at $800{ }^{\circ} \mathrm{C} \pm 25{ }^{\circ} \mathrm{C}$ until a fixed weight is obtained. Then the ash level is determined.

$$
\% \text { ash }=\frac{\text { ash weight }(\mathrm{g})}{\text { sample weight }(\mathrm{g})} \times 100 \% \ldots \ldots 3
$$




\subsection{Viscosity Measurement}

A solution of $1 \% \mathrm{~b} / \mathrm{v}$ sodium alginate is made using a distilled water solvent, then stirred until homogeneous then the viscosity is measured using a Brookfield Viscometer. Measurements are carried out at room temperature by using spindle number 3 at $50 \mathrm{rpm}$.

\subsection{Detemination of $\mathrm{pH}$}

Solution of $1 \% \mathrm{~b} / \mathrm{v}$ sodium alginate which has measured viscosity, then measured its $\mathrm{pH}$ using a $\mathrm{pH}$ meter.

\section{Preservation of Mango Fruit with Na-alginate}

Five mangoes each dipped in sodium alginate solution with concentrations of $0 \mathrm{ppm}, 5 \mathrm{ppm}, 10 \mathrm{ppm}$, 15 ppm, 20 ppm, 25 ppm, 30 ppm, 35 ppm, 40 ppm, 45 ppm, 50 ppm. Dyeing is carried out for 1 hour, until it is estimated that the entire pore of the mango is closed. The mango is removed one by one from the container and the entire surface is dried with tissue carefully. Dried fruit is packaged in translucent plastic that has been perforated and labeled according to the concentration of the solution. Each fruit in plastic packaging is stored regularly at room temperature, until the skin of the mango changes from green to yellow or reddish. The storage time in the day is recorded as the inhibition of Naalginate extract from Sargassum sp. to the process of preserving mangoes.

\section{Test Vitamin C on Mangoes Levels}

A total of 100 gram of the blended mango sample was finely weighed in a beaker. Then added with $100 \mathrm{~mL}$ of distilled water, then filtered with gauze to separate the filtrate. A total of $5 \mathrm{~mL}$ of filtrate was put into the Erlenmeyer flask, 3 drops of starch were added and $20 \mathrm{~mL}$ of distilled water. Then titrated with 0.01 $\mathrm{N}$ iodine solution until a blue color is formed. Then note the volume of iodine titration results. $1 \mathrm{~mL} 0.01 \mathrm{~N}$ Iodine $=$ $0.88 \mathrm{mg}$ vitamin $\mathrm{C}$.

\section{RESULT AND DISCUSSION}

\section{Sodium-Alginate Extraction}

Based on the results of extraction of sodium alginate from samples of brown algae type Sargassum sp. a young brown colored extract was obtained, then measured the spectrum using the FTIR (Fourier Transform Infra Red) spectrophotometer. From the results of the analysis obtained absorption peaks which show the functional groups of alginate constituents. The sodium alginate spectrum was extracted (Figure 1) compared to sodium alginate from the plant (Figure 2). From the spectrum functional groups can be identified which show the characteristics of sodium alginate so that an illustration can be seen in Table 1 . 


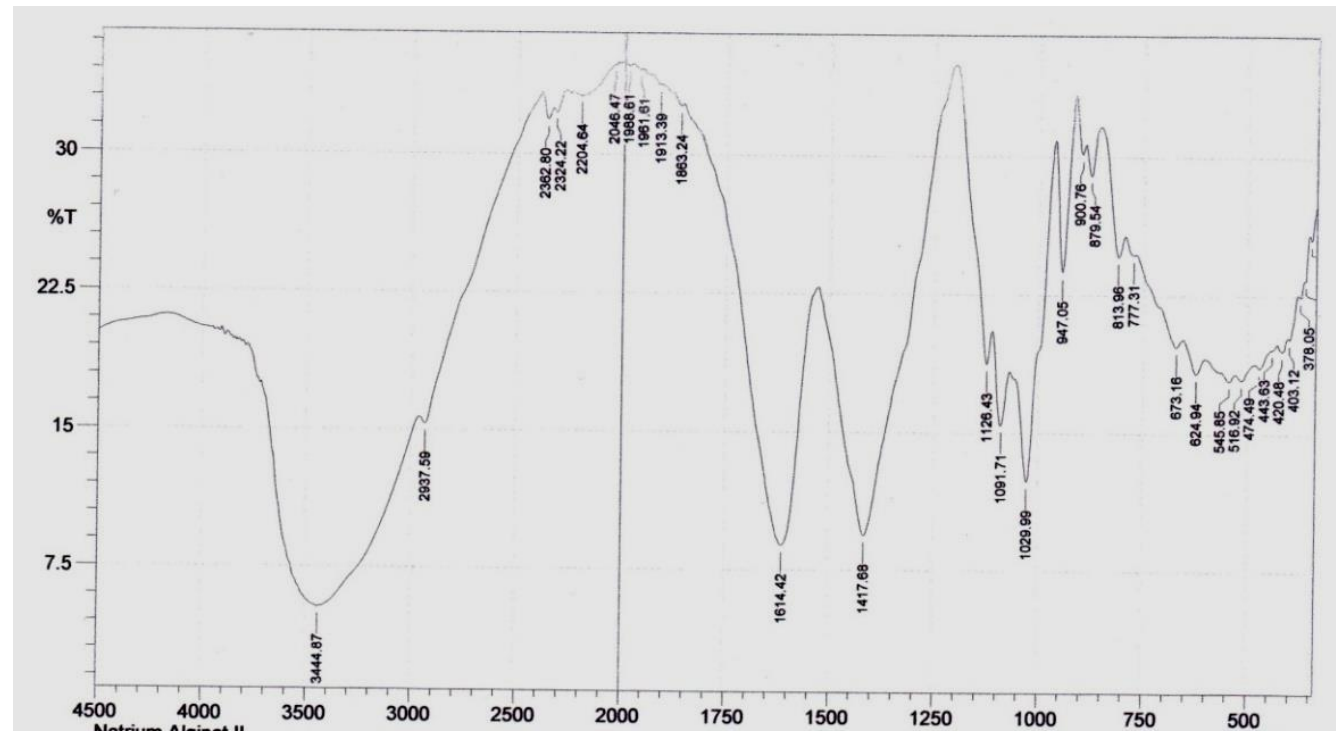

Figure 1. Extract of FTIR sodium alginate spectrum

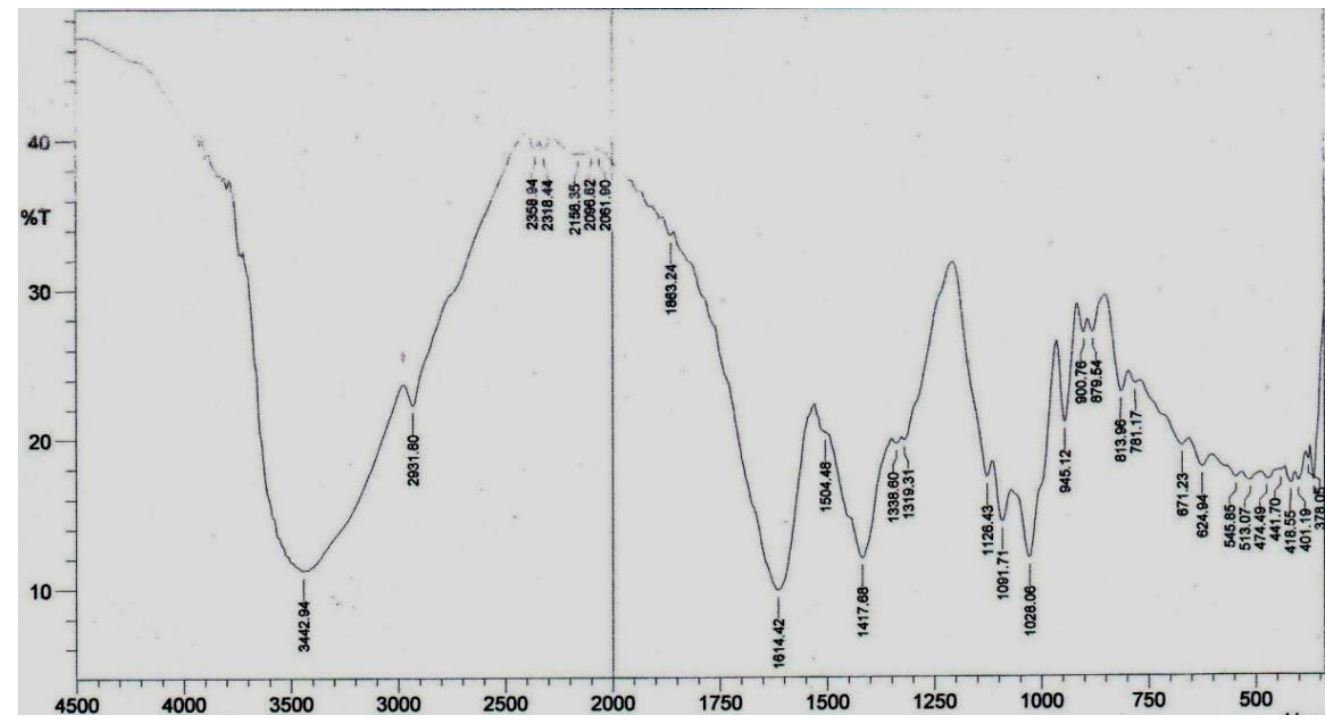

Figure 2. Spectrum of FTIR sodium alginate factory

Table 1. Data on FTIR spectrum of sodium alginate extracted from sodium alginate factory (Yulianto, 2007)

\begin{tabular}{|c|c|c|c|}
\hline \multicolumn{2}{|c|}{ Wave number $\left(\mathrm{cm}^{-1}\right)$} & \multirow{2}{*}{$\begin{array}{l}\text { Interpretation of } \\
\text { functional groups }\end{array}$} & \multirow{2}{*}{$\begin{array}{l}\text { Reference of } \\
\text { wave number } \\
\left(\mathrm{cm}^{-1}\right)\end{array}$} \\
\hline $\begin{array}{l}\text { Extraction } \\
\text { Results }\end{array}$ & Factory & & \\
\hline 3444,87 & 3442,94 & Hydroxyl Group $(\mathrm{O}-\mathrm{H})$ & $3500-3200$ \\
\hline 1614,42 & 1614,42 & Carbonyl Group $(\mathrm{C}=\mathrm{O})$ & $1600-1680$ \\
\hline 1126,43 & 1126,43 & \multirow{3}{*}{ Carboxyl Group (C-O) } & \multirow{3}{*}{$1000-1300$} \\
\hline 1091,71 & 1091,71 & & \\
\hline 1029,99 & 1028,06 & & \\
\hline 1417,68 & 1417,68 & $\mathrm{Na}$ in alginate isomers & 1614 dan 1431 \\
\hline
\end{tabular}


The IR spectrum pattern in the 4000-1000 $\mathrm{cm}^{-1}$ area shows that extracted sodium alginate has a functional group similar to factory alginate. The presence of peaks in the area of about $3500-3200 \mathrm{~cm}^{-1}$ indicates the presence of a hydroxyl $(\mathrm{O}-\mathrm{H})$ group that binds to hydrogen. Wave number $1680-1600 \mathrm{~cm}^{-1}$ shows the presence of a carbonyl group $(\mathrm{C}=\mathrm{O})$ as an aromatic group, $1300-1000 \mathrm{~cm}^{-1}$ indicating the presence of a carboxyl (C-O) group. Sodium in the alginate isomer is located at the absorption peak of $1614 \mathrm{~cm}^{-1}$ and $1431 \mathrm{~cm}^{-1}$. The absorption peak at 900$890 \mathrm{~cm}^{-1}$ shows the typical area of guluronic fingerprints, while 850-810 $\mathrm{cm}^{-1}$ shows the typical area of mannuronic fingerprints. The existence of a typical area of guluronate and mannuronate fingerprints is a marker that the samples studied are alginate compounds.

The FTIR spectrum obtained showed that sodium alginate from the factory and extraction results showed almost the same spectrum and had the structure of manuronic acid and guluronic acid. Based on the results of quantitative analysis including the parameters of levels, $\mathrm{pH}$, viscosity, moisture content, and ash content compared with the sodium alginate quality standards based on the Food Chemical Codex, the quality parameter data is obtained as follows:

Table 2. Data from the parameters of sodium alginate quality analysis

\begin{tabular}{lccc}
\hline \multicolumn{1}{c}{$\begin{array}{c}\text { Quality } \\
\text { Parameters }\end{array}$} & $\begin{array}{c}\text { Extracted Na- } \\
\text { alginate }\end{array}$ & $\begin{array}{c}\text { Na-alginate from } \\
\text { the factory }\end{array}$ & $\begin{array}{c}\text { Quality standards } \\
\text { for Na-alginate }\end{array}$ \\
\hline $\begin{array}{l}\text { Na-alginate } \\
\text { Levels(\%) }\end{array}$ & 22,42 & - & $>18$ \\
\hline $\mathrm{pH}$ & 10,97 & 5,52 & $3,5-10$ \\
\hline Viscosity (cps) & 90 & 80 & $10-5000$ \\
\hline Water Levels (\%) & 11,27 & 12,50 & $<15$ \\
\hline Ash Levels (\%) & 41,47 & 25,98 & $18-27$ \\
\hline
\end{tabular}

The sodium alginate level obtained from the sample in this study was $22.42 \%$. When compared with the results of previous research by Rasyid (2004) with a sample of $20.30 \%$ Turbinaria decurrens from Barranglompo Island, the results obtained in this study had higher levels of sodium alginate. But when compared with the results of research by Rasyid and Rachmat (2002) that the levels of sodium alginate from the extraction of Sargassum sp. from
Pari island at $24.32 \%$, Turbinaria deccureens from Otangala Island by $30.19 \%$, Turbinaria conoides from Pari Island at 25.65\% (Rasyid, 2004), and Sargassum polycystum from Pameungpeuk at $28.60 \%$ (Rasyid, 2003 ), the results of the study in the sample in this study had lower levels.

Winarno (1990) states that the level of alginic acid from algae stems of Laminaria species in older plants is relatively more stable compared to the 
young ones. Possible differences in harvest age (take time) also affect the levels of Sargassum echinocarphum sodium alginate. Another factor is the difference in water conditions at the time of sampling. As stated by McHugh (1987) that alginate is present in the brown algal cell wall which acts to provide flexibility to the algae itself. That is why, brown algae that grow in rippling (turbulent) waters usually have higher alginate content than those that grow in relatively calm waters.

Sodium alginate is very stable at $\mathrm{pH}$ 5-10, 1\% sodium alginate solution factory has a 5.52 of $\mathrm{pH}$ while sodium alginate extraction has a higher $\mathrm{pH}$ which is $\mathrm{pH}$ 10.97, a significant difference in $\mathrm{pH}$ is suspected because washing after addition of $\mathrm{NaOH}$ is only done 1 time so that there is still a lot of residual $\mathrm{NaOH}$ left in sodium alginate.

According to Winarno (1990) that the viscosity value of sodium alginate varies greatly between 10-55 cps (1\% solution concentration). In addition there are three types of standard values for the viscosity of sodium alginate traded (SIGMA 2008), which are $1000 \mathrm{cps}$ (high viscosity), 300 cps (medium viscosity) and 20-30 cps (low viscosity). High quality alginate will form a hard gel and a very thick solution. Brown algae that have these criteria are Ascophylum, Durvillaea, Ecklonia, Laminaria, Lessonia, Macrocystis and Sargassum.

Based on the results of research on the extraction of sodium alginate from Sargassum sp. obtained a viscosity value of $90 \mathrm{cps}$, this value is higher than the viscosity of sodium alginate from the factory that is equal to $80 \mathrm{cps}$. Possible differences in the location of growth (including water conditions, $\mathrm{pH}$, salinity, light, depth, nutrients) which is one of the causes of differences in viscosity values (Rasyid, 2009) shown by sodium alginate extracted from sodium alginate. Another factor that might be the cause of the difference in the value of viscosity produced in this study is the quality of the sample used which is likely to have a significant effect on the levels of sodium alginate and the value of the resulting viscosity.

The water level of sodium alginate obtained in this study from Sargassum $s p$. is $11.27 \%$ lower when compared with the sodium alginate water content of the factory $12.50 \%$, this value meets the standard of water content set by the Food Chemical Codex (1981) which is a maximum of $15 \%$.

The ash level in extracted sodium alginate shows the presence of mineral salts, with values ranging from $41.47 \%$ this result is higher when compared to the $25.98 \%$ sodium alginate ash level of the factory, this is thought to occur due to the presence of salt residues which not washed with distilled water resulting in increasingly difficult the process of separation and purification between alginate with impurities in alginate solution including inorganic minerals, so it is possible that there are still many impurities that are included in the alginate solution and can increase the ash level. 
2. The Inhibitory Power of Sodium Alginate Against the Process of Mango Fruit Maturation

Observation of the inhibition of sodium alginate on the ripening process of mangoes was carried out with several parameters, namely, based on shelf life and the content of vitamin $\mathrm{C}$ of mangoes. Observation of the inhibition of sodium alginate solution as edible coating on mangoes seen from the shelf life of mangoes with a ratio of several concentrations of sodium alginate and mango solutions without coating as a control. Observation of mango samples is recorded based on the shelf life of the mangoes.

Table 3. The shelf life of mango fruit with sodium alginate as a coating material

\begin{tabular}{|c|c|c|c|c|c|c|}
\hline \multirow{2}{*}{$\begin{array}{l}\text { Na-alginate } \\
\text { solution } \\
\text { levels (ppm) }\end{array}$} & \multicolumn{6}{|c|}{ Mango shelf life (days) } \\
\hline & $\begin{array}{c}\text { Sample } \\
1\end{array}$ & $\begin{array}{c}\text { Sample } \\
2\end{array}$ & $\begin{array}{c}\text { Sample } \\
3\end{array}$ & $\begin{array}{c}\text { Sample } \\
4\end{array}$ & $\begin{array}{c}\text { Sample } \\
5\end{array}$ & Average $\pm \mathrm{SD}$ \\
\hline $0 *$ & 4 & 7 & 5 & 6 & 4 & $5,2 \pm 1,30$ \\
\hline 5 & 7 & 7 & 6 & 10 & 5 & $7,0 \pm 1,87$ \\
\hline 10 & 7 & 5 & 8 & 10 & 10 & $8,0 \pm 2,12$ \\
\hline 15 & 10 & 10 & 10 & 12 & 10 & $10,4 \pm 0,89$ \\
\hline 20 & 16 & 18 & 16 & 14 & 12 & $15,2 \pm 2,28$ \\
\hline 25 & 16 & 12 & 16 & 13 & 11 & $13,6 \pm 2,30$ \\
\hline 30 & 10 & 12 & 10 & 10 & 13 & $11,0 \pm 1,41$ \\
\hline 35 & 13 & 10 & 15 & 12 & 11 & $12,2 \pm 1,92$ \\
\hline 40 & 11 & 12 & 8 & 10 & 7 & $9,6 \pm 2,07$ \\
\hline 45 & 12 & 7 & 5 & 9 & 8 & $8,2 \pm 2,59$ \\
\hline 50 & 5 & 7 & 5 & 11 & 7 & $7,0 \pm 2,45$ \\
\hline
\end{tabular}

*Without coating

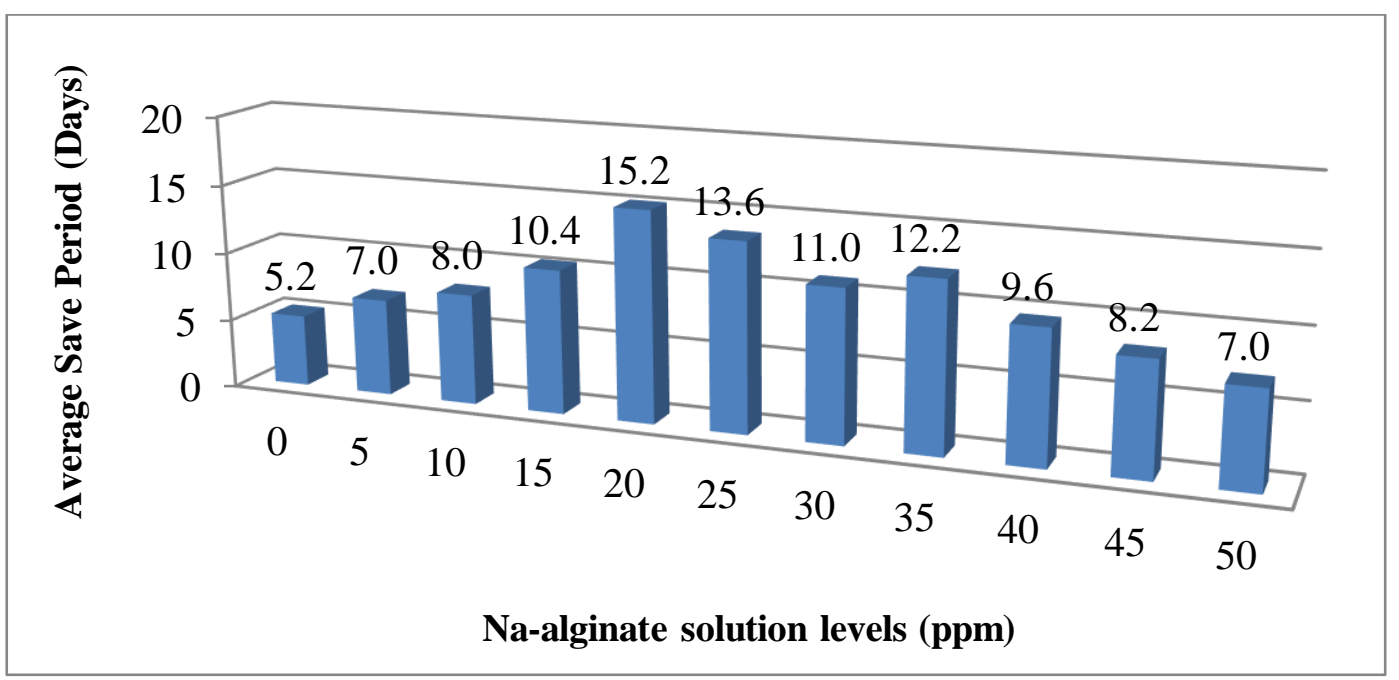

Figure 3. Graph the relationship between the concentration of Na-alginate solution and the shelf life of mangoes 
From the research carried out a graph is obtained as shown in Figure 3 where at a concentration of $0 \mathrm{ppm}$ the shelf life of mangoes is 5.2 days, 5 ppm for 7 days, $10 \mathrm{ppm}$ for 8 days, $15 \mathrm{ppm}$ for 10,4 days, $20 \mathrm{ppm}$ for 15,2 days, $25 \mathrm{ppm}$ for 13,6 days, $30 \mathrm{ppm}$ for 11 days, 35 days for 12,2 days, 40 days for 9,6 days, $45 \mathrm{ppm}$ for 8,2 days and $50 \mathrm{ppm}$ for 7 days. This shows that the use of sodium alginate solution affects the shelf life of mangoes, the shortest shelf life is shown by samples without coating sodium alginate solution for 5,2 days and the longest shelf life obtained by coating sodium alginate 15 ppm for 15,2 days. Concentrations below $20 \mathrm{ppm}$ are thought to not completely cover the pores of the mango, while high concentrations are thought to damage the mango cell wall.

During storage, fruit ripening and aging processes occur which causes a decrease in the physical condition of the fruit. Sodium alginate can be used to maintain the quality of mangoes because of the ability of sodium alginate to cover the pores on the skin of mangoes so that it can inhibit the respiration of air from the outside into the fruit. Reduced air respiration will prevent the occurrence of chemical and enzymatic reactions triggered by oxygen. In addition, the nature of alginate which easily absorbs water can release water and cause an increase in the concentration of dissolved solids in the mangoes. This condition will increase the osmotic pressure in mango, thus inhibiting the growth of microorganisms and slowing the rate of chemical and enzymatic reactions.

\section{Measurement of Chemical Parameters in Mango}

Changes in the chemical content of mangoes are evaluated during storage time. The chemical changes observed were the content of vitamin $\mathrm{C}$. Observations were made by comparing samples of mango without coating and mango with the use of sodium alginate as a coating material at an optimum concentration of $20 \mathrm{ppm}$ in each range of 2 days. The observation of changes in vitamin $\mathrm{C}$ levels in mangoes during storage is shown in Figure 4.

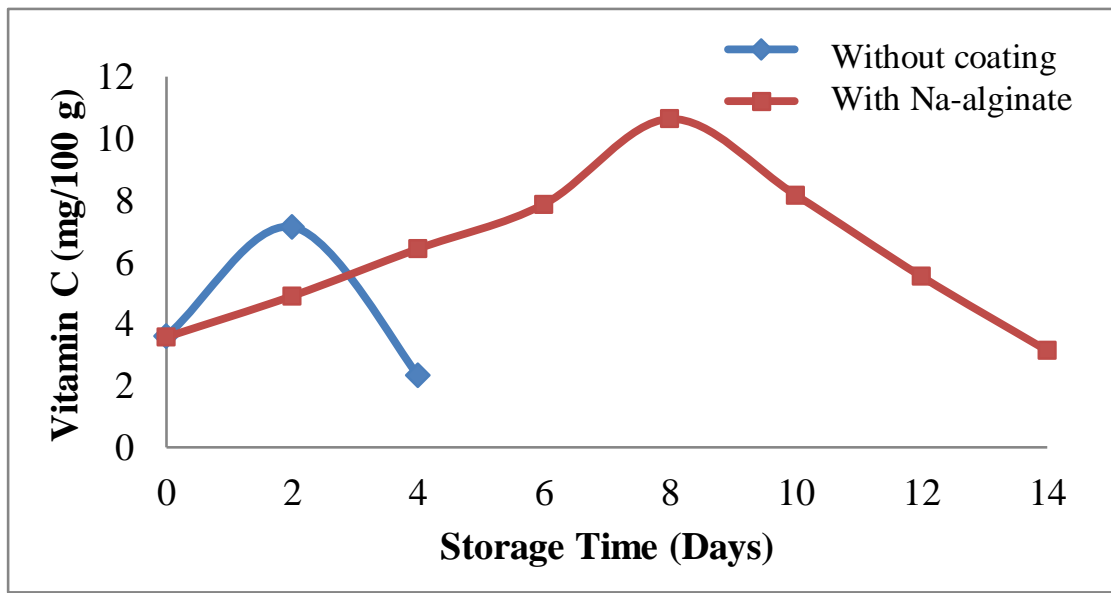

Figure 4. Graph of changes in vitamin $\mathrm{C}$ levels in mangoes 
From the above graph it can be observed that, the level of vitamin $\mathrm{C}$ in the first day analysis did not show a significant difference with almost the same value. While the analysis on the second day, began to show differences, where samples without coating sodium alginate showed higher levels of vitamin C compared to samples of sodium alginate using sodium alginate coating. In the fourth day analysis, the level of vitamin $\mathrm{C}$ in the sample without coating decreased sharply, in contrast to the sample with sodium alginate coating the level of vitamin $\mathrm{C}$ continued to increase and found the optimum point in the eighth day analysis, then continued to decline after storage reached 10 days.

Based on the results of the analysis it is known that on day 0 , the level of vitamin $\mathrm{C}$ in the sample without coating sodium alginate is $3,60 \mathrm{mg} / 100 \mathrm{~g}$, higher than the levels of vitamin $\mathrm{C}$ in the mango fruit by coating a sodium alginate solution of $20 \mathrm{ppm}$ which is equal to $3,57 \mathrm{mg} / 100 \mathrm{~g}$. These results did not show a significant difference in vitamin $\mathrm{C}$ levels in the difference in sodium alginate concentration.

On the second day, the sample flesh without coating rose to its maximum point with vitamin $\mathrm{C}$ levels: $7,13 \mathrm{mg} / 100 \mathrm{~g}$, higher when compared with coatings, namely: $4,9 \mathrm{mg} / 100 \mathrm{~g}$. This shows that the mangoes without coating are ripe, while the coating is still immature.

On the fourth day there was a change in value, the vitamin $C$ level in the sample without coating decreased, which was $2,33 \mathrm{mg} / 100 \mathrm{~g}$ lower than the sample using sodium alginate solution coating which actually showed an increase in vitamin $\mathrm{C}$ levels of 6,43 $\mathrm{mg} / 100 \mathrm{~g}$.

On the sixth day, testing on samples without sodium alginate coating was no longer carried out because the condition of the sample had decayed, observation of vitamin $\mathrm{C}$ levels continued for samples using sodium alginate solution coating, ie, sixth day: $7,87 \mathrm{mg} / 100 \mathrm{~g}$, the eighth day seen the sample with the highest vitamin $\mathrm{C}$ level, namely: $10,63 \mathrm{mg} / 100 \mathrm{~g}$, tenth day: 8,17 $\mathrm{mg} / 100 \mathrm{~g}$, twelfth day: $5,53 \mathrm{mg} / 100 \mathrm{~g}$ and the fourteenth day showed the lowest vitamin C level, namely: $3,13 \mathrm{mg} / 100 \mathrm{~g}$. This is because the mango sample has started to rot and besides that vitamin $\mathrm{C}$ is also easily degraded, both by temperature, light and ambient air so that vitamin $C$ levels are reduced. This result is in accordance with the opinion of Winarno (1984) that vitamin C levels in fruit will increase until the fruit is ripe, and will decrease when the level of maturity has been exceeded.

\section{CONCLUSION}

Based on the results of the research that has been done, it can be concluded that sodium alginate has been successfully extracted from brown algae of Sargassum sp. with Na-alginate level of $22,42 \%$, water level of $11,27 \%$, ash level $41,47 \%$, viscosity of $90 \mathrm{cps}$ and $\mathrm{pH}$ of 10,97. Extract of sodium alginate can be used as a coating material to inhibit the process of ripening and decay of mangoes. Maximum inhibition with 
coating using sodium alginate solution obtained an average shelf life of mangoes for 15,2 days at an optimum concentration of $20 \mathrm{ppm}$.

\section{REFERENCES}

BPTP SULSEL, 2007, Recommendation on Citrus and Mango Cultivation Technology, Publication Directory Bulletin BPTP Sul-Sel, 1 (1), 1.

Indriani, H., and Sumarsih, E., 2003, Cultivation of Processing and Marketing of Seaweed, Penebar Swadaya, Jakarta.

Kadi, A., and Atmadja, W.S., 1988, Algae Type Seaweed: Reproduction, Production, Cultivation, and Post Harvest, Research Center for Oceanography-LIPI, Jakarta.

McHugh, D. J., 1987, Production, Properties and Uses of Alginates dalam Mc Hugh, D. J. (ed), Production and Utilization of Products from Commercial Seaweed, FAO, Fisheries Technical Paper 288, Rome.

Muchtadi., And Tien R., 1989, Food Processing Technology, Bogor Agricultural Institute, Bogor.

Rasyid, A., and Rachmat, R, 2002, Modification of the extraction method of sodium alginate to increase its viscosity value. Paper presented at the National Seaweed Seminar, Mini Microalgae Symposium and First Congress of the Indonesian Faculty of Physiology October 23-25, 2002 at Sedona Hotel, Makassar: 6 things.

Rasyid A., 2003, Brown Algae (Phaeophyta) As a Source of
Alginate, Oseana, XXVIII (1), 3338.

Rasyid, A., 2004, Turbinaria conoides as one of alternative raw materials of sodium alginate processing in Indonesia,In: B. SULISTYO, E.S. HERUWATI, A. SUDRADJAT, I.G.S. MERTHA and A.H. PURNOMO (eds.),International Seminar on Marine and Fisheries, The Agency for Marine and Fisheries Research, Jakarta, 225-227.

Rasyid, A., 2009, Comparison of the quality of sodium alginate in several types of brown algae, Oceanology and Limnology in Indonesia, 35 (1), 57-64.

Rehm, B. H. A., 2009, Alginates: Biology and Applications, Springer, New Zealand.

Siswati, J., Syarief, R., and Soekarto, S. T., 2002, Extraction of Alginate from Sargassum sp. Seaweed. and its Application as an Ice Cream Stabilizer, Postgraduate Forum, 25 (4), 357-364.

SIGMA, 2008, Biochemical reagents for life science research,Sigma Aldrich Pte.,Ltd, 2706 pp.

Winarno, F., G., 1984, Chemistry of Food and Nutrition. Gramedia, Jakarta.

Winarno, F. G., 1990, Seaweed processing technology, Sinar Harapan Library, Jakarta.

Yulianto, K., 2007, Effect of Sodium Hydroxide Concentration on Sodium Alginate Viscosity extracted from Sargassum duplicatum J.G. agardih (Phaeophyta), Oceanology and Limnology in Indonesia, 33 (295306). 